\title{
Trafficking of women for the purpose of sexual exploitation in Europe
}

\author{
Gautam Kok \\ Maastricht University \\ Gautam.kok@alumni.maastrichtuniversity.nl
}

\begin{abstract}
Tens of thousands of women and girls are trafficked from mainly poorer to richer regions of Europe and forced into prostitution. Traffickers abuse the poor socio-economic situation of young women in these poorer regions to exploit them into prostitution.

Sex trafficking poses a huge impact on society. Besides the economical side - sanctions for not complying with certain anti-trafficking efforts or health care costs for victims the political- and social impact is drastic. Social impact for victims is huge: during their trafficking they face extreme violence, coercion, and rape, which leave both psychological as physical marks after their return. Additionally, drug use by victims will eventually place another burden on society.

In order to stop sex trafficking the pre-departure state, transit stage, exploitation stage and demand side need to be targeted. The pre-departure state is most important for source countries. The exploitation- and demand stages are tightly intertwined with legislation on prostitution. When prostitution is legalized and demand is high, exploitation is a natural result. Sweden has shown that demand can be strongly decreased by criminalizing the purchase of sex. By not criminalizing sales of sex, victims of sexual exploitation cannot be prosecuted.
\end{abstract}

The European Commission has recently adopted a law prohibiting the purchase of sex, therewith copying this system. Country-specific adaptations might be necessary, as European countries are very different and deal with trafficking in very dissimilar ways. Adopting demand-tackling legislation might not have the desired effect in Eastern European source countries. Additionally, European countries must continue to work together.

Sex trafficking seemingly follows basic economics: when there's no demand, there's no market, and therefore supplies will drop. Having looked at the different efforts countries 
make, it can be concluded that - although all stages of sex trafficking need to be targeted - eliminating the demand for sex workers seems to work as a best method.

\section{Keywords}

Trafficking, exploitation, prostitution, Europe, legislation

\section{Introduction}

Annually, tens of thousands of women from around the world are lured into Western and Central Europe. They are promised modeling careers, study programs abroad or a job that will earn them enough money to care for their children $(1,2)$. They all have one thing in common: vulnerable women hoping for better lives are being tricked and exploited into forced prostitution.

Working in the sex-industry - which will further be referred to as prostitution - and sexual exploitation are often confused with one another (3). Selling sexual services is legal in the majority of European. Some countries even require prostitutes to pay taxes (4). In contrast, sexual exploitation is "any actual or attempted abuse of a position of vulnerability, differential power, or trust, for sexual purposes, including, but not limited to, profiting monetarily, socially or politically from the sexual exploitation of another", according to the United Nations (5). In other words, prostitution may but does not necessarily always include sexual exploitation.

In human trafficking, the "recruitment, transportation, transfer, harboring or receipt of persons, by means of the threat or use of force [...], for the purpose of exploitation" (6), three elements can be distinguished. First, there is the 'act', which includes recruitment, transportation and transfer, harboring and the receipt of persons. Second, the 'means' consist of the threats made or use of force in order to control the victims, and other forms of coercion. They also include fraud, deception, abuse of power and abuse of a vulnerable other, and giving or receiving payments or benefits in order to gain control over another person. Third, the 'purpose' may be sexual exploitation or prostitution, labor exploitation, organ removal or slavery (7). Any combination of these three elements is human trafficking. In case of sex trafficking, exploitation refers to sexual exploitation.

The success rate of sex trafficking is surprisingly high. Women often do not dare to report their situation due to fear or feelings of shame or guilt, specifically regarding trafficking for sexual services $(8,9)$. Furthermore, their often-illegal stay in a country contributes to fear of eviction by the police after reporting. Additional factors include language barriers or pressure for sending remittances on a regular basis (3). All of these factors contribute to the low risk traffickers face of being detected $(7,9)$. 
For Europe alone, the United Nations Office on Drugs and Crime (UNODC, 10) has calculated an astonishing amount of 70,000 new victims per year, and estimates the total amount of women being trafficked for sexual exploitation at any given time at 140,000. These numbers may, however, not reflect the actual amount of women being trafficked or sexually exploited, as it is difficult to make an accurate estimation. Public awareness is still low, and only recently have countries started making an effort to expose the details of trafficking (11). Any form of trafficking violates the Universal Declaration of Human Rights (12) and countries are obliged to protect, support and help any victim of trafficking under section II, article 6 of the United Nations Protocol to Prevent, Suppress and Punish Trafficking in Persons, Especially Women and Children, [...], in UNODC (6).

Though almost every country worldwide deals with trafficking, be it as a sending country, a transit country, a receiving country or any combination of these (9), this paper will mainly focus on European countries. There will be 1) written about the victims, who they are, from where they come and why they are trafficked, 2) elaborated on how sex traffickers work and the routes they use, 3 ) an analysis of the impact on society, including the economical aspect and health risks and 4) a discussion on anti-trafficking legislation, interventions and initiatives. The main purpose of this paper is finding out what the best legal practice is to counter sex trafficking in Europe.

Literature for this paper has been limited to reports from global, European and national agencies and bodies thereof, books on human trafficking, and scientific papers and -reviews for general and country-specific information, supplemented with national laws and critical news items and press releases thereabout. All literature was selected unbiased, not based on the tone. Both positive and negative pieces were taken into account in order to give a clear and neutral perspective on the topic.

\section{Victims}

On a global scale, adult women and girls account for over three in four victims of trafficking. More than a quarter (27\%) of these victims are underage. However, these data vary immensely between regions. For example, whereas in Europe and Central Asia 16\% of trafficking victims is a minor, the amount of minors trafficked is $68 \%$ in Africa and the Middle East (7). All data from these reports are what has been detected and reported by countries, and covers only a fraction of all cases. For example, the data from UNODC (7) includes roughly 29,000 reported cases between 2007 and 2010, whereas global trafficking and sexual exploitation figures already reach into the millions for children only $(13,14)$.

With $68 \%$ of trafficking victims sexually exploited, Europe and Central Asia are the world's leader, and this percentage steadily increases year by year (15). Other forms of exploitation 
include forced labor, almost equally high in the Americas, South Asia, Africa and the Middle East (44-49\%) but 'only' 31\% in Europe and Central Asia (7).

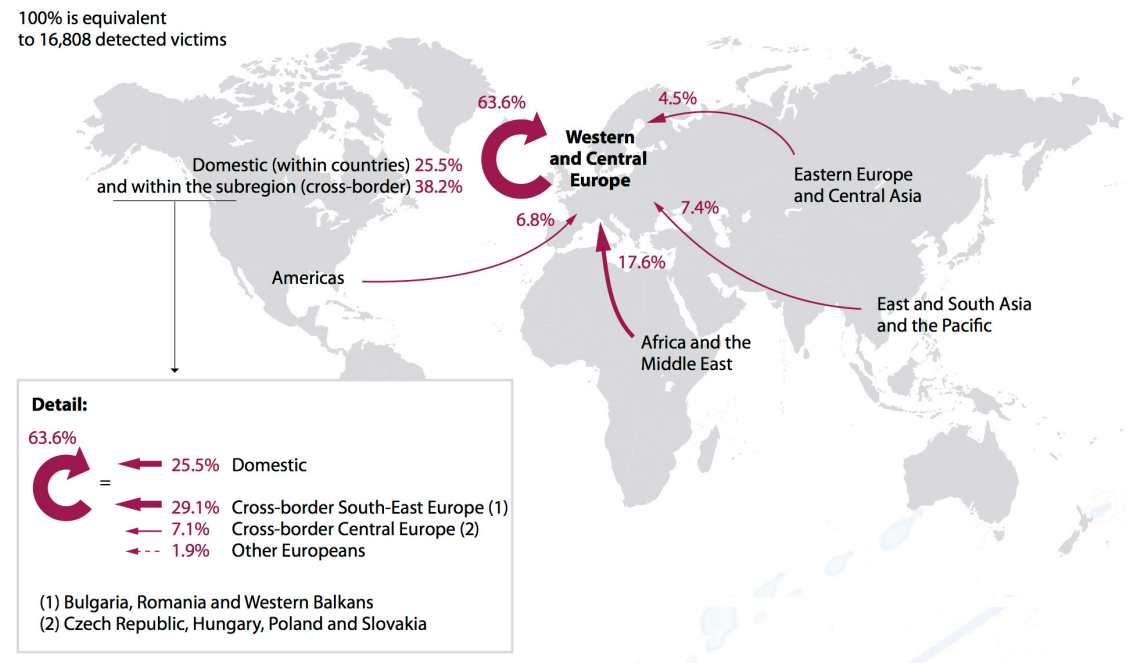

Figure 1. Origin of victims trafficked to Western and Central Europe (as percentage of total victims detected there between 2007 and 2010), taken from UNODC (7)

It is important to keep in mind that there is no stereotypical victim. Although trends in socio-economic status, gender and nationality have been observed (7), both males and females of any socio-economic background, nationality and education-level can fall into the hands of traffickers (16). However, this does not mean certain groups are not at a higher risk than others. The United Nations request special attention for women and children, whom they perceive as more vulnerable (7).

Obviously, women are subject to several forms of violence during and after being trafficked, one of the reasons that sex trafficking is a major issue for the victims. It might not be surprising that sexual violence, including rape, is the most common form of coercion against the victims. Traffickers often practice these methods in order to break the women mentally and emotionally, so they become obedient and can be forced into sex work (17). Other forms of violence against victims include physical abuse, causing serious injuries and long-lasting health issues, and exposure to potentially life-threatening diseases, like HIV-AIDS and subsequently tuberculosis (18). Furthermore, victims are liable to serious legal consequences such as prosecution or deportation, as their stay in a foreign country is 
often unregistered and illegal (19). The fear of these legal consequences causes the victims to remain in the background. Due to a combination of different strategies traffickers use to control their victims, such as threats towards the victims' families (20), victims are unlikely to come forward with their stories. This way, traffickers can often remain undetected.

Several socio-economic factors tend to drive the flow of trafficking. Overall, women are trafficked from less developed, poorer regions to more developed, richer regions (7). This trend can be observed globally, but also within Europe. Most victims originate from the Balkan and Central Europe. The vast majority of identified victims in Europe come from within Europe itself $(3,7,10)$, not from far-away foreign countries as is often believed. In line with socio-economic factors driving the flow, Brazil, Nigeria, China and Russia - all developing countries according to the IMF (21) - are the most important non-European sources of trafficked women (15).

\section{Traffickers}

Worldwide, there were 460 different trafficking routes discovered between 2007 and 2010, according to the UNODC (7). Precise assessment of the major routes proves to be extremely difficult, due to the underground nature of the crime. The fear of both their traffickers and legal consequences such as deportation cause women to remain silent about their situation. Even when spoken to, they often do not identify themselves as victim of trafficking (20). This contributes to the difficulty of research into the networks and routes.

The South Western- and Southern criminal hubs, as defined by Europol (22), act as the main entry sites for Europe. Victims from far away reach the South Western hub by air, which then functions as a transit point for redistribution throughout Europe. Victims that pass this hub are mainly Chinese laborers and South Americans that are exploited in the sex industry. The Southern hub is both a transit and destination area. Victims mostly come from Africa, Eastern Europe and China, for either labor- or sexual exploitation (22, 23). Almost every country in the world plays a role in trafficking. Some countries are sources of victims, others function merely as transit countries, yet others are purely destination countries, or any combination thereof $(1,23,24)$. In table 1 , the main function in sex trafficking of European countries is listed. Tiers assigned represent tiers given to countries by the U.S. Department of State (25). They judge a country on their efforts against trafficking. Tier 1 means governments comply to the minimum standards of the TVPA, countries with tier 2 do not fully comply but are making significant efforts, and countries with tier 3 do not comply to the TVPA and do not make efforts to do so. Countries on the watch list will be downgraded if they fail to increase efforts against trafficking. 
Based on the data from this table (table 1), a clear distinction can be made between countries that are sources of victims, transit countries and the destination countries. Moldova, Slovakia and the Ukraine are pure source countries (22-24, 26). Albania, Bulgaria and Romania are both source- and transit countries. It is interesting to note that except for Slovakia, all of these countries are classified as tier 2 (WL) or -3. The Czech Republic and Poland are the only countries that are a source of sex trafficking victims, a transit country, as well as a destination country. A possible explanation is the economic rise these countries experienced after $2004(27,28)$, which may have contributed to the increase in local demand for sex workers. Furthermore, they are, together with Slovakia and Macedonia, the only Eastern European tier 1 countries.

Table 1. List of European countries (and Russia) as source, transit or destination countries, adapted from Kligman (1) and updated with data from Shelley (23) and Surtees (24). Tiers from U.S. Department of State (25).

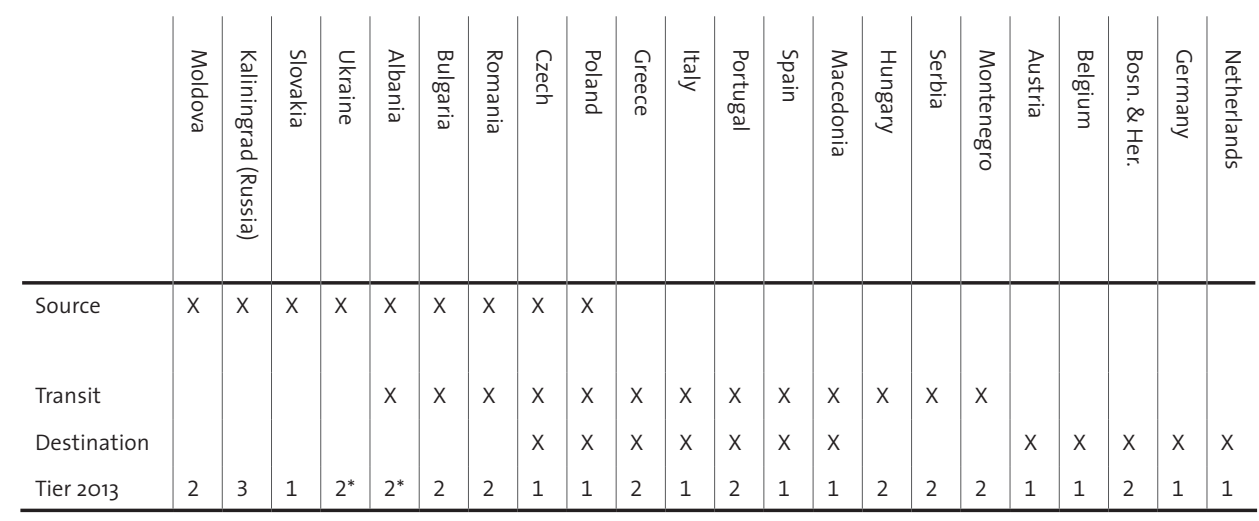

* watch list

Spain, Italy and Greece are major transit and destination countries. Especially Spain's southern regions are marked as destinations, due to high domestic demand and large amounts of tourism (23). Italy and Greece belong to the five main destination countries. The other three countries are Germany, Belgium and the Netherlands (23). Remarkably, three of these five countries, namely Germany, Greece and the Netherlands, have legal and regulated prostitution, brothel ownership and pimping. Moreover, they are the only European countries with this regulation. This implies that regulation has an adverse effect, an interesting idea that will be discussed in further detail later on.

Though varying amongst countries, women seem to have an active role in trafficking. 
Women are most often involved in collecting money from clients (24\%), controlling/ guarding the victims of trafficking at the place of exploitation (21\%) and recruitment of new victims (19\%) (7). Especially the latter is a worrying observation: countries with more convictions of women show higher amounts of girls as victims. Considering the amount of women and girls as trafficking victims, this observation is not unexpected. Often women fulfill these positions as they can more easily gain the trust of victims. Conversely, it is unfair to automatically blame the women for recruiting. There are known cases where a victim of trafficking was tricked into recruiting others. For example, in one case, a woman recruited her sister, before she realized her own fate of sexual exploitation (29). It shows the insidiousness of the techniques that traffickers use.

Traffickers easily adapt to the local conditions. New social media appear to become increasingly important in recruiting girls (30). While traffickers often wait until the victim reaches the age of 18 for the actual sexual exploitation, the recruitment phase often starts when the girls are much younger (30). This way - in an attempt to remain unnoticed by authorities - traffickers seemingly comply with legislation in destination countries such as the Netherlands and Germany, where prostitution is legalized and regulated (prostitutes need to be older than 18). Kelly (20) has listed more methods of recruitment, including deception, either through marriage offers, employment offers without notion of sex work, employment offers in the entertainment and dancing industry, and being sold by family members or a boyfriend. Especially the latter seems to be an important way for recruiters to deceive their victims.

Moreover, traffickers often abuse the vulnerable position of women of poorer socioeconomic status. A way of doing so is by falsely promising them a way to escape their current situation. (Young) women are often offered seemingly legitimate, well-paying jobs as waitresses (9), in landscaping, or child- and elder care. Traffickers may even convince their victims' parents that the jobs are legitimate (31). Through "second wave" recruitment, victims return home to recruit others - they receive between 150- and 3,500 euro (April 20, 2014: 1 US dollar = 0.72 euro) per newly recruited victim $(2,32)$. Victims are often resold, the earnings for the recruiters and resellers increasing up to a maximum of 22,000 euro (depending on the country) each step (29,33).

Even after having worked in a certain place for a while, a victim is likely to be transported to another place (34). For non-European Union (EU) citizens that move to the EU, regular tourist visas are most often used - either real or forged (9). Moreover, liberating the EU visa requirements for Romanians has led to an increase in women being trafficked to Western Europe (1). This probably extends to states like Bulgaria (which joined the EU in 2007). After arrival, victims of sex trafficking often are robbed of their passports. Travel expenses that 
were paid for in advance by their traffickers and promised 'included' housing/living costs, adding up to an unaffordable amount, need to be reimbursed in the timeframe of their visa validity. These practices lead to so-called debt-bondage $(35,36)$. Due to the lack of papers, debt-bondage equals virtual imprisonment for many victims (9).

\section{Impact}

Exploitation, both sexual and for labor, are a developmental issue (37). The consequences and impact are not region-specific, but are rather universal. In most source, transit and destination countries, traffickers typically have tight connections with the government and authorities (24), for example to help obtain counterfeit documents (38) or for the police to 'turn a blind eye'. This may even extend to a situation where the police hands an escaped victim of (sex) trafficking back over to the traffickers (31). Many non-governmental organizations (NGOs) have called that trafficking would not exist if corruption were eradicated (31). This position of corruption inevitably is both a major societal and political issue. In addition, the continuous and immense violation of human rights contributes to trafficking in general being a political issue. The United Nations' Office of the High Commissioner for Human Rights (39) supports the NGOs by saying that corruption underlies the violation of human rights. Corruption and hence human trafficking have adverse effects on a country's "economically and politically disadvantaged," who are dependent on public goods (39).

The different tiers are not only used for classification. Sequential assignment of the lower tiers (2, 2 WL and 3 ) could have serious consequences for the countries. Countries in tier 3 face strong economic and political sanctions including, but not limited to, blocking of aid or funding from the International Monetary Fund and World Bank, with an exception for humanitarian aid, and withdrawing educational activities for the countries' governments (25). In economic terms, billions of euros $(7,32,40)$ worldwide flow into the criminal circuit through sex trafficking, placing a large economic burden on countries.

Besides the impact and risk on a societal, economical and political level, sex trafficking places a huge burden on the victims. During all stages of trafficking the victims can and will suffer from (health) risks. Victims will continuously face physical, sexual and mental abuse by their traffickers and clients. They are likely to start using drugs to cope with their condition and have poor or no access to healthcare (34). Also, they are at permanent risk of sexually transmitted infections (STIs) and pregnancy. Shockingly, almost 90\% of sex trafficking victims were found to have at least one STI, and these numbers are even higher in countries where clients are unlikely use a condom (Turkey, Cyprus, United Arab Emirates). It is estimated that 15 to $25 \%$ of victims are pregnant when they return (24). 
Furthermore, the social wellbeing of victims is strongly confined. Victims are isolated from family and friends, and often far away from home. Social support is therefore absent. In a survey amongst victims, none of the women reported feeling free (34). They face situations in which they are strongly restricted in freedom of movement, time and activities, not to forget language barriers (34). All in all, $84 \%$ of victims return with neurotic disorders, including depression and anxiety, aggression, insomnia, post-traumatic stress disorder and more (24).

\section{Anti-trafficking}

\section{The Netherlands, Germany, and Greece}

Germany, Greece and the Netherlands are the only European countries that have fully legalized and regulated prostitution, brothel ownership and pimping. The Netherlands has the highest number of trafficking victims and leads countries like Romania, Bulgaria and Italy (15), which implies that legalization has not worked or even had adverse effects. The Dutch government lifted a ban on brothel ownership and pimping issued in 1911. By new law from October 2000, prostitution was made a regular profession. Prostitutes are from now on required to pay income taxes (41). Any form of exploitation and prostitution below the age of 18 remains illegal. It is, however, worth noticing that prostitutes below the age of 18 will, in fact, not be prosecuted. Legal age to visit a prostitute is 16 . By not prosecuting prostitutes that are below 18 (because they might be victims of sex trafficking), the Dutch government hopes to decrease incidence of prostitution of minors. Furthermore, anyone who sets a minor to prostitution can be prosecuted under the new law (42).

A problem with this new Dutch law was that it excluded any non-EU sex worker. Migrant sex workers were left with two options: leaving the Netherlands, or entering the criminal world. The new law therefore led to the closing of many brothels in for example Amsterdam in 2000 (43), pushing the prostitutes into the criminal circuit. Even though many prostitutes in this country see themselves as independent businesswomen, it would be wrong to assume that sex trafficking does not occur in the Netherlands (41). In fact, legalization has led to more sex trafficking (40).

Very recently, the Dutch government has started a new offence against sex trafficking. Major cities started closing brothels in July 2013 after stricter regulation from October 2011 (44), in addition to closing many brothels since 2007. Just months ago, new legislation to limit sex trafficking and exploitation was proposed (45). The aim is to increase the minimum age for prostitutes from 18 to 21 , prosecute brothel owners who have employ prostitutes under the age of 21 and prosecute clients who undergo sexual acts with 
prostitutes under 21. The latter will be punished with a maximum sentence of 1 year in prison. The law further restricts brothel owners and will also apply to escort services (46). These actions indicate that the Dutch government is aware of the adverse side of legalization of prostitution, brothel ownership and pimping.

Germany, after many years of political discussions, forced the Prostitution Act in 2002. Through enacting the Prostitution Act, the German government hoped to improve the legal-and social status and working conditions of prostitutes. It was also meant to make it easier for prostitutes to step out of the business. Another major point of this act was to stop criminality in this field and hence halt organized crime (47). Before this act, prostitution was legal (prostitutes needed to pay taxes since 1964 (48)), though not recognized as a profession or type of work. Third parties were not allowed to organize activities including prostitution, and prostitutes were not allowed to advertise. Furthermore, prostitution as a business had no legal status.

However, this legislation led to several problems, one of which the employment contracts. Especially the legal position of prostitutes versus brothel owners is unclear. From a prostitute's perspective, should she follow all orders of her employer (brothel owner) or fear getting fired? Would the social security benefits prostitutes would benefit from weigh up to being forced to provide services as stated in the contract? These questions led to many prostitutes being employed under different contracts such as housekeeping, hostess, etc. Also, several prostitutions denied contracts, because it was unclear what the effect of such a contract would mean for ever getting a regular job again (47).

For Germany, after having this legislation for over a decade, it has turned out to have the opposite effect of what the government had in mind. The Prostitution Act is merely pumping more money into pimps and brothel owners, and not solving anything about trafficking. Changes in existing laws led to significantly fewer pimps convicted (151 in 2000 to 32 in 2011), because pimping is legal, but exploitation - considered taking more than $50 \%$ of the prostitutes' money - is not. Exploitation seems very hard to prove (49). Whereas the Netherlands and Germany are classified as tier 1 countries, Greece was assigned tier 2 (table 1), indicating there is more the Greek government can do to prevent trafficking. Greek law from 1999 certified prostitution. In order to become certified, prostitutes have to be over the age of 19 and not being married, in addition to the standard requirements like not having STIs or being convicted for murder or seduction of a minor. Prostitution is only legal in brothels, though prostitutes often solicit in the streets as well (50).

One major problem with Greek legislation is the strict requirement of two-weekly medical examinations of sex workers. Many prostitutes therefore do not register, making it difficult to control the sector. Any prostitute who is not registered cannot benefit from 
(free) healthcare checkups and HIV testing (51). Besides this, there is no real prevention against trafficking of women or girls. When police detects prostitutes in the street, the prostitutes are often violently taken into custody. Migrant prostitutes will be deported. However, there are sounds of traffickers buses transport prostitutes back over the border into Greece. The police is thought to play a role in this as well (50).

\section{Spain and Italy}

Spain has neither legalized nor banned prostitution. After years of arguing, the Spanish parliament decided not to regulate anything (4). By doing this, men cannot be prosecuted for visiting prostitutes. Although brothel owning and pimping is illegal, Spain's attitude has created a habitat that attracts traffickers (52).

In Spain, around $90 \%$ of the women in prostitution are under control of criminal organizations. The government is active and on different levels and prosecutes many trafficking offenders and has been increasing efforts over the past few years. Penalties include imprisonment from five to twelve years. In 2012, 13 offenders of sex trafficking were convicted (25). This number is relatively low.

The Italian Penal Code does not specifically mention prostitution, but does criminalize brothel ownership and pimping. Its abolitionist view drove Italy to prohibit the aid, facilitation or exploitation of prostitutes. Therefore, employing prostitutes is severely punishable. Furthermore, working in a closed quarter - house, club, hotel, etc. - is illegal, but one sex worker in a private apartment is tolerated (53).

The Italian government rigorously prosecutes and convicts anyone they detect to have a role in trafficking (53). However, they do not proactively screen for possible victims. It could well be this lack of screening that causes sex trafficking, especially the transit of victims, to remain a major problem in the country. Although still tier 1, the Italian government further reduced efforts in 2012, by cutting budgets for anti-trafficking initiatives, public awareness and for NGOs (25).

\section{Moldova, Bulgaria, and Romania}

Europol has identified Moldova, Bulgaria and Romania as the major source countries of trafficking victims in Europe (23), although the latter two are also transit countries. All three have prostitution, brothel ownership and pimping illegalized, though Bulgarian law does not specifically address prostitution. In the rural parts of these countries, violence against women is a serious problem (25) and contributes to their vulnerability for traffickers, as described.

What is typical about these countries is that the traffickers and recruiters are mainly 
locals, recruiting within their own ethnic group or even within their own family. The three countries are all classified as tier 2, indicating they make substantial effort against trafficking, though there is room for improvement. All three government identify large amounts of traffickers per year, though this does not seem to withhold traffickers from their activities (25).

Especially Romania is making increasing efforts of prosecuting sex trafficking offenders, and numbers of convictions have increased over the last years. Although having started awareness campaigns, the Romanian government has cut budgets for anti-trafficking initiatives over the last year, which possibly limits the potential decrease in trafficking (25). Bulgaria is making less progress in fighting sex trafficking, both on prevention side and law enforcement efforts. Additionally, they seem to have difficulty in fighting involved government officials (25).

Being one of the poorest countries of Europe, Moldova is struggling to fight sex trafficking. Especially in the poorer rural regions, violence against women is a large problem and many victims are recruited. A 2005 law explicitly prohibits trafficking (54), which was previously only targeted by the country's constitution from 1994. The law further specifically mentions exploitation. Also in 2005, the Moldovan government created a plan of action against trafficking, partially financed by the United Nations' International Labor Organization (ILO). From 2010 onwards, the government has made significant efforts to stop trafficking. One example is the launch of a strong program to identify and help victims, which has proven to work. In 2013, double the number of traffickers were convicted compared to 2012 - a large gain, especially when considering the country's struggle with corrupt judiciary system (25).

\section{Sweden}

In 1998 the ILO called for recognition of prostitution as work (55). Where countries such as the Netherlands and Germany adopted this view of sex work as women's right over their own body and a way to make money through it as any other job, Sweden decided to adopt the complete opposite.

It is its criminalization of purchasing sex, not selling it, what makes Sweden so special. In May 1998, Swedish government voted for a law that would not criminalize the victims, as these persons often are "a weaker party who is exploited by those who want only to satisfy their sexual drive" (52). It went into force on 1 January 1999. Sweden's definition of prostitution collides with the definition adopted in the introduction. Its law clearly states that prostitution is seen as a form of sexual violence against women, not as merely working in the sex industry. Later, in 2005, the law has been adapted to include the purchase of sex and attempts to, even when through a third person (52). 
By illegalizing the purchase of sex, demand noticeably dropped. The idea behind this is that without the demand from the men's side, there would be no large sex industry and hence no sex trafficking. In Sweden, prostitution and sex trafficking are seen as linked, harmful practices, and are seen as the country's largest threat towards gender equality (52). As with the purchase of sex, they therefore prohibit any related matters such as brothel ownership, pimping (and obviously trafficking).

The Swedish' focus on the demand side has had benefits over the last years. Being a highly developed region, Sweden would classify as a destination country. Still, the number of sex trafficking victims is currently very low. Exact numbers on sex trafficking victims and the decline therein are unavailable due to reasons mentioned earlier. Critics, i.e. Jordan (56) embrace this argument to argue on the effectiveness of the Swedish model, whereas many others endorse it. There is evidence, however, of decreased supply in Sweden. Based on a personal conversation with the Swedish National Rapporteur on Trafficking in Women by Ekberg (52), revenues for traffickers dropped due to several demand-related issues, such as buyers' fear of prosecution, abolished street prostitution (private prostitution costs more) and higher operational costs such as apartments.

\section{Interventions and initiatives}

The aforementioned United Nations Protocol to Prevent, Suppress and Punish Trafficking in Persons, Especially Women and Children (6) is one of the three Palermo protocols, which is currently ratified by $159 \mathrm{UN}$ member states. Based on this protocol, signees meet every two years to discuss best practices on fighting human trafficking. It furthermore strengthens international cooperation in criminal matters.

For many years, sex work feminists have been soliciting for legislation of prostitution. They argued that anti-prostitution laws were the drive behind prostitution. They furthermore hoped that by giving prostitutes the same status as any other employee they would get social security, better access to health care services and other benefits employees have (57). Increasing state regulation, however, does not significantly improve the situation for women. Especially regarding organized crime: the numbers of sex trafficking victims have only increased after prostitution, brothel ownership and pimping were legalized in certain countries (57). More than half of the sex workers in the Netherlands and Germany are either migrant sex workers or sex trafficking victims (58).

Due to an inclusion of countries such as Bulgaria and Romania to the EU the common destination countries experienced a large influx of sex workers. Europe is, however, proactively working on new methods and initiatives to fight sex trafficking. In February 2008, the European Commission (59) started a new method for managing the outside 
borders of the EU. This led to a decrease of external sex trafficking victims, but trafficking remains a problem. In March 2009, the European Commission (60) adopted two proposals. The first proposal aims to fight the trafficking in human beings in general through stricter legislation and penalties. Furthermore, it directs at the creation of independent bodies to monitor the progress EU member states make in fighting trafficking. The second proposal explicitly targets the sexual abuse and exploitation of children, and focuses on the new media used increasingly by traffickers.

In 2011, the European Commission (61) set up a 'Group of Experts on Trafficking in Human Beings', chaired by the EU Anti-Trafficking Coordinator Myria Vassiliadou to investigate and coordinate actions. In a directive adopted in March 2011 by the European Commission (62), EU member states were obliged to adopt new working methods on abandoning human trafficking by stricter prosecution of traffickers, increased investigation of the subject and national rapporteurs to regularly check progress. It also strengthened the guidance and assistance of victims, as well as directions on prevention.

Following the Swedish model where selling sex is legal but purchasing it is illegal, in March 2014 a large majority of the European Parliament voted in favor of a resolution to criminalize the latter. The idea behind this is to tackle the demand side of prostitution, which is, according to Vassiliadou, exactly what is needed to stop sex trafficking (63). Some countries with legalized prostitution (e.g., the Netherlands, Germany), however, may not agree to this upcoming EU legislation. While still evolving, their opinion on prostitution is that it is a regular profession like any other.

Still, Europe needs to find a way to deal with millions of men whom they might criminalize. It needs to be taken into account that Sweden belongs to the world's richest countries, has a low population density and has relatively few sex workers and sex trafficking victims. Other countries that have adopted similar legislation or considered doing so, Norway, Finland, and Iceland, share these characteristics with Sweden (56). It remains uncertain if similar laws will work for poorer or denser countries in South Europe, let alone in countries like India.

Although an overarching regulation by the European Union or United Nations is the key to eliminating sex trafficking, the importance of local efforts and collaborations between countries should not be ignored. Obviously every country has its own view on how to deal with sex trafficking. Furthermore, they have different methods to deal with sex trafficking. There is one specific type of collaboration that seems very effective: the Joint Investigation Team (JIT), coordinated by Europol. This is a method adopted by different countries, in which two or more EU member states collaborate for a limited period of time (64). Such collaborations between the Balkan and the rest of the EU have improved cooperation as well as coordination between different authorities, which has a positive influence on 
the protection of victims (65). Another successful example of a JIT is operation GOLF (UK Metropolitan Police and Romanian National Police), an investigation in which 126 people were arrested and convicted for human trafficking (66).

\section{Best practices and conclusion}

Sex trafficking is a major issue in today's world. Hundreds of thousands of women and girls are trafficked from mainly poorer regions to richer regions and forced into prostitution. Though many victims in Europe come from outside the continent, the vast majority is trafficked within Europe. The major European source countries include Bulgaria, Moldova and Romania, whereas Greece, Spain and Italy are Europe's main transit countries. The Netherlands and Germany are its primary destination countries.

Although there is no stereotypical victim, victims are often young women from poor socioeconomic status. Traffickers abuse their situation by promising them a better life abroad, and exploit them into prostitution at arrival. Often, victims are used as recruiters, and when women are involved, the amount of young girls trafficked increases.

Often unrecognized, sex trafficking poses a huge impact on society. Besides the economical side - sanctions for not complying with certain anti-trafficking efforts or health care costs for victims - the political- and social impact is drastic. The social impact for victims is huge: during their trafficking they face extreme violence, coercion, and rape, which leave both psychological as physical marks after their return. Additionally, drug use by victims will eventually place another burden on society.

On a political level, different views on the topic exist. This division has caused Spain to keep prostitution unmentioned in laws, which noticeably stimulates trafficking. Even between countries there are strong political differences. Both wealthy and on other levels similar countries, Sweden and the Netherlands have adopted exact opposite laws: the Netherlands has fully legalized and regulated prostitution (by means of try-out), whereas Sweden has attempted to tackle the demand side of sex trafficking by criminalizing the purchase of sex. Poorer (source) regions have criminalized prostitution and all that comes with it, but remain to struggle with stopping sex trafficking. This can be partially attributed to the lack of budget for anti-trafficking initiatives and law enforcement, but corruption also plays an important role. The effort countries make against sex trafficking is graded annually by the U.S. Department of State tier system.

There are several factors that need to be taken into account when dealing with the issue. First of all, in order to stop sex trafficking all four different stages need to be considered: 1) the pre-departure state, 2) the transit stage, 3) the exploitation stage and 4) the demand side. The pre-departure state is most important for source countries. Though the 
legislation is there, these countries need to make continued efforts to fight trafficking, possibly by public awareness campaign and a better way of finding and prosecuting recruiters. With the introduction of the Schengen area in the EU, transit within the EU has become much easier while trafficking from outside the EU into it has become much more difficult, confirmed by the numbers (figure 1). Especially on the eastern side of the EU border (Poland, Slovakia) trafficking has been well targeted by specialized EU training of border control of countries concerned.

The last two, the exploitation stage and the demand stage, are tightly intertwined with legislation on prostitution. The case of the Netherlands has shown that when prostitution is legalized and demand is high, exploitation is a natural result. It has led to reconsideration of these laws, creating an environment in which the purchase of sex is slowly being limited. The usefulness of this new legislation has yet to prove itself in the coming years. Sweden on the other hand, has shown that demand can be strongly decreased by criminalizing the purchase of sex. By not criminalizing sales of sex, victims of sexual exploitation cannot be prosecuted. Careful consideration of this new legislation is needed, however, as it remains arguable whether or not selling sex can be perceived as a woman's right over her own body. By criminalizing one side of this business, women's rights could arguably be limited. Although argued by some, this Swedish system is generally believed to work. This stretches to such an extent that the European Commission has very recently adopted a law to prohibit the purchase of sex, therewith copying the Swedish system. Countryspecific adaptations might be necessary, as European countries are very different and deal with trafficking in very dissimilar ways. Adopting demand-tackling legislation might not have the desired effect in Eastern European source countries. Additionally, European countries must continue to work together. While they cooperate through initiatives as Joint Investigation Teams, the last successful cooperation of this type was years ago. Being a border-crossing problem, all countries dealing with sex trafficking need to adjust their anti-trafficking efforts with one another in order to improve efficiency. Besides legislation, a massive European (or global) awareness campaign could yield beneficial effects as well in both source- and destination countries.

Still, sex trafficking seemingly follows basic economics: when there's no demand, there's no market, and therefore supplies will drop. Having looked at the different efforts countries make, it can be concluded that - although all stages of sex trafficking need to be targeted - eliminating the demand for sex workers seems to work as a best method. Still, a fair balance between prosecuting sex buyers and focus on sex workers' and sex trafficking victims' social rights and their protection is necessary. Care for victims will remain to be most important, no matter how strong the decrease. 


\section{Role of the student}

As an International Health honours undergraduate student in Biomedical Sciences, Gautam Kok wrote this thesis under supervision of Dr Bart Rutten. The student proposed the topic, searched literature and wrote all parts of this narrative after discussing the basic structure with the supervisor. This is a summary of the original version, submitted to Maastricht University on May $9^{\text {th }}$.

\section{References}

1. Kligman G. Trafficking women after socialism: to, through, and from Eastern Europe. Social Politics: International Studies in Gender, State \& Society. 2005;12(1):118-40.

2. Amnesty International. Kosovo (Serbia and Montenegro): "so does it mean that we have the rights?" protecting the human rights of women and girls trafficked for forced prostitution in Kosovo. London: Amnesty International, 20046 May. Report No.: EUR 70/010/2004

3. BNRM. Mensenhandel - derde rapportage van de nationaal rapporteur. Den Haag: Bureau National Rapporteur Mensenhandel en Seksueel Geweld tegen Kinderen, 2004 July. Report No.

4. ProCon.org. 100 countries and their prostitution policies 2013 [updated 23 December; cited 2014 April 18]. Available from: http://prostitution.procon.org/view.resource.php?resourcelD=000772.

5. United Nations. Special measures for protection from sexual exploitation and sexual abuse. 2003. p. 3.

6. UNODC. United Nations convention against transnational organized crime and the protocols thereto. New York: United Nations, 2004.

7. UNODC. Global report on trafficking in persons. New York: United Nations publication; 2012. 98 p.

8. BNRM. Mensenhandel in en uit beeld. Cijfermatige rapportage (2007-2011). Den Haag: Bureau National Rapporteur Mensenhandel en Seksueel Geweld tegen Kinderen, 2012.

9. Kelly L, Regan L. Stopping traffic, exploring the extent of, and responses to trafficking in women for sexual exploitation in the UK. London: Home Office; 2000.49 p.

10. UNODC. Trafficking in persons to Europe for sexual exploitation. Vienna: United Nations publication, 2010978 92-1-130295-0.

11. Bishop RA, Morgan CV, Erickson L. Public awareness of human trafficking in Europe: how concerned are European citizens? Journal of Immigrant \& Refugee Studies. 2013;11(2):113-35.

12. UN General Assembly. Universal declaration of human rights. 194810 December. Report No.: 217 A (III).

13. World Vision Australia. Fact sheet: trafficking for the purpose of sexual exploitation. In: Australia WV, editor. 2009.

14. U.S. Department of State. Trafficking in persons report. United States of America, 20084 June. Report No.

15. European Commission. Trafficking in human beings. Luxembourg: European Commission, 201311 April. Report No.: ISBN 978-92-79-22842-1.

16. Polaris Project. The victims, polaris project, combating human trafficking and modern-day slavery Washington, DC2014 [cited 201419 April]. Available from: http://www.polarisproject.org/human-trafficking/overview/thevictims.

17. UNESCO. Integration of the human rights of women and the gender perspective. United Nations Economic and Social Council, 200029 February. Report No.: Contract No.: E/CN.4/2000/68.

18. UNFPA. State of world population 2003 - making 1 billion count: investing in adolescents' health and rights. New York: United Nations Population Fund, 2003 E/31,000/2003 Contract No.: ISBN 0-89714-670-0. 
19. The Advocates for Human Rights. Legal consequences of trafficking Minneapolis2005 [updated 1 September 2005; cited 201418 April]. Available from: http://www.stopvaw.org/Legal_Consequences_of_Trafficking.

20. Kelly L. Journeys of jeopardy: a commentary on current research on trafficking of women and children for sexual exploitation within Europe. EU/IOM European Conference on Preventing and Combating Trafficking in Human Beings: A Global Challenge for the 21st Century; 16 September. London2002. p. 48.

21. IMF. World economic outlook. Washington, DC: International Monetary Fund, 2012 ISBN 978-1616352462.

22. Europol. Trafficking in human beings in the European Union. The Hague: Europol, 20111 September. Report No.: 2565-84.

23. Shelley L. Human smuggling and trafficking into Europe: a comparative perspective. Washington, DC: Migration Policy Institute, Migration TCo; 2014 February. Report No.

24. Surtees R. Victims of trafficking in South-Eastern Europe. Geneva: International Organization for Migration, 2005 Contract No.: ISBN 978-92-9068-254-7.

25. U.S. Department of State. Trafficking in persons report. United States of America, 2013.

26. Surtees R. Traffickers and trafficking in Southern and Eastern Europe: considering the other side of human trafficking. European Journal of Criminology. 2008;5(1):39-68.

27. Vozáb J. Integrating interventions: the need for improved impact on local economic and employment development in the Czech Republic. Berman Group; GHK Consulting Ltd.; CERGE-El, 201120 May. Report No.

28. Belka M. How Poland's EU membership helped transform its economy. The Group of Thirty. Washington, DC2013. p. 73.

29. Pennington JR, Ball AD, Hampton RD, Soulakova JN. The cross-national market in human beings. Journal of Macromarketing. 2009;29(2):119-34.

30. BNRM. Mensenhandel - negende rapportage van de nationaal rapporteur. Den Haag: Bureau National Rapporteur Mensenhandel en Seksueel Geweld tegen Kinderen, 2013 September. Report No.

31. Richard AON. International trafficking in women to the United States: a contemporary manifestation of slavery and organized crime. Center for the Study of Intelligence, 2000 April. Report No.

32. Hughes DM. The "Natasha" trade: the transnational shadow market of trafficking in women. Journal of International Affairs. 2000;53(2):625-51.

33. Beeks K, Amir D. Trafficking and the global sex industry: Lexington Books; 2006.

34. Zimmerman C, Yun K, Shvab I, Watts C, Trappolin L, Treppete M, et al. The health risks and consequences of trafficking in women and adolescents. Findings from a European study. London: London School of Hygiene \& Tropical Medicine (LSHTM), 2003.

35. Pearson E. Human rights and trafficking in person: a handbook. Bangkok20oo December. $100 \mathrm{p}$.

36. Coffey PS, Phariss AV, Renaud T. Literature review of trafficking in persons in Latin America and the Caribbean. USAID, 2004 August. Report No.

37. Koettl J. Human trafficking, modern day slavery, and economic exploitation. Washington, DC: The World Bank, 2009 May. Report No.

38. Transcrime. A pilot study on three European Union key immigration points for monitoring the trafficking of human beings for the purpose of sexual exploitation across the European Union. European Commission, 2002 April. Report No.: ISBN 978-88-8443-160-8.

39. OHCHR. Human rights and anti-corruption Geneva: United Nations; 2014 [cited 201421 April]. Available from: http://www.ohchr.org/EN/Issues/Development/GoodGovernance/Pages/AntiCorruption.aspx.

40. Farell A. Human trafficking: new directions for research. International Organization for Migration, 2008.

41. Siegel D. Human trafficking and legalized prostitution in the Netherlands. Temida. 2009;12(1):5-16.

42. G. Vermeulen BMEDB. Betaalseksrecht: naar regulering of legalisering van niet-problematische prostitutie?: Maklu; 2007. 
43. 'Ramen' en prostituees in Amsterdam [press release]. Amsterdam: Gemeente Amsterdam, 11 December 2007.

44. Rijksoverheid. Wet regulering prostitutie en bestrijding misstanden seksbranche. In: Rijksoverheid, editor. 32211. Den Haag2011.

45. Wijziging prostitutiewet ingediend bij Tweede Kamer [press release]. 5 March 2014.

46. Rijksoverheid. Novelle wet regulering prostitutie en bestrijding misstanden seksbranche.33885. Den Haag2014.

47. Kavemann B, Rabe $\mathrm{H}$. The act regulating the legal situation of prostitutes - implementation, impact, current developments. findings of a study on the impact of the German prostitution act. Berlin:Sozialwissenschaftliches FrauenForschungsInstitut e.V., 2007 September. Report No.

48. Bundesfinanzhof. BStBI III 1964. In: Bundesfinanzhof, editor. GrS 1/64 S1964.

49. DER SPIEGEL. Unprotected: how legalazing prostitution has failed. DER SPIEGEL. 201326 May;Sect. 22.

50. TAMPEP. Final report. Transnational AIDS/STD Prevention Among Migrant Prostitutes in Europe / Project (TAMPEP), 2002 February. Report No.

51. Mak RP. General conclusions and recommendations. TAMPEP, 20036 March. Report No.

52. Ekberg G. The Swedish law that prohibits the purchase of a sexual service: best practices for prevention of prostitution and trafficking in human beings. Violence against women. 2004;10:1187-218.

53. TAMPEP. Sex work, migration, health. Amsterdam: European Network for HIV/STI Prevention and Health Promotion among Migrant Sex Workers (TAMPEP), 2009

54. Law on preventing and combating trafficking in human beings, 164-167/812 (2005).

55. Raymond JG. Legitimating prostitution as sex work: UN international labour organization calls for recognition of the sex industry. 2003

56. Jordan A. The Swedish law to criminalize clients: a failed experiment in social engineering. Center for Human Rights \& Humanitarian Law. 2012(4):17.

57. Limoncelli SA. The trouble with trafficking: conceptualizing women's sexual labor and economic human rights. Women's Studies International Forum. 2009;32(4):261-9.

58. Monzini P. Sex traffic: prostitution, crime, and exploitation: Zed; 2005.

59. Managing borders in a globalised world [press release]. 13 February 2008.

6o. The EU Commission cracks down on modern slavery and child sexual abuse [press release]. Brussels: European Commission,, 25 March 2009.

61. European Commission. Commission decision of 10 august 2011 on setting up the group of experts on trafficking in human beings and repealing decision 2007/675/EC 2011.

62. European Commission. Directive 2011/36/EU of the European Parliament and of the council of 5 April 2011 on preventing and combating trafficking in human beings and protecting its victims, and replacing council framework decision 2002/629/JHA Official Journal of the European Union. Strasbourg2011.

63. Oppenheim M. MEPs vote to criminalise buying sex. The Guardian. 201426 February.

64. Council of the European Union. Joint investigation teams manual. Brussels: Council of the European Union, 20114 November. Report No.: Contract No.: 15790/1/11.

65. European Commission. Human trafficking in the EU: slavery of our times. In: European Commission, editor. 2013.

66. Europol. Operational successes 2010 [updated October; cited 201425 April]. Available from: http://www. europol.europa.eu/content/page/operational-successes-127 